Piwulang 8 (1)(2020)
Teaching
http://journal.unnes.ac.id/sju/index.php/piwulang

\title{
PENGEMBANGAN MEDIA PEMBELAJARAN SESORAH DENGAN VIDEO PEPIPAK (PEMBELAJARAN PIDATO NGAPAK) UNTUK SISWA KELAS IX SMP DI TEGAL
}

\author{
Nur Izza Fadhliani' ${ }^{1}$, Bambang Indiatmoko ${ }^{2}$, Agus Yuwono ${ }^{3}$ \\ 1,2,3 Jurusan Bahasa Jawa, Fakultas Bahasa dan Seni, Universitas Negeri Semarang, Indonesia \\ Corresponding Author: nurizza.fadhliani2@gmail.com ${ }^{1}$
}

\begin{abstract}
Abstrak
Tujuan penelitian ini yaitu (1) untuk mengetahui kebutuhan pembelajaran pidato berbahasa Jawa, (2) untuk mengetahui prototipe pengembangan media video pepipak, (3) untuk mengetahui validasi produk video pepipak untuk pembelajaran pidato. Penelitian ini menggunakan pendekatan penelitian pengembangan (research \& development). Pengembangan media ini melalui lima tahap yaitu (1) potensi masalah, (2) pengumpulan data, (3) desain produk, (4) validasi uji ahli, (5) perbaikan desain. Instrument yang digunakan yaitu instrument nontes berupa angket. Dari hasil analisis kebutuhan pembelajaran pidato berbahasa Jawa menunjukkan siswa dan guru membutuhkan media video pepipak. Hasil prototipe media video pepipak berdurasi 04.18 menit yang terdiri dari: (1) pembuka media, (2) isi media, (3) penutup. Validasi uji ahli media dan materi diperoleh presentase $71.76 \%$ dan $78,82 \%$ yang termasuk kategori baik dengan beberapa revisi, yaitu pada pembukaan media yang ditambahkan identitas pembuat media.

Kata Kunci: media pembelajaran; sesorah; video

\section{Abstract}

Objectives of the research are (1) to know the necessary of learning Javanese speech, (2) to know the prototype development of media pepipak video, (3) to know the products validation of media pepipak video for speech learning. This research uses research and development approach. The development of this media is through five steps, i.e (1) potential problems, (2) data collection, (3) products design, (4) test expert validation, (5) design improvement. Instrument of this research is non test instrument in form questionnaire. Based on the analysis results, the necessary of learning Javanese speech shows the teacher and the students need media pepipak video. The prototype results of media pepipak video has duration 04.18 minutes which consist of: (1) opening of media, (2) content of media, (3) closing of media. The test expert validation of the materials and media is obtained percentage $71.76 \%$ and $78,82 \%$ which includes good category with some revisions, that is on the opening of media which is added the identity of the media maker.

Keywords: learning media; speech; video
\end{abstract}


Nur Izza Fadhliani, dkk/ Piwulang 8 (1) (2020)

\section{PENDAHULUAN}

Siswa masih mengalami kesulitan untuk berkomunikasi dalam bentuk pidato menggunakan bahasa Jawa dengan baik dan benar. Siswa kurang tertarik dengan pembelajaran bahasa Jawa di sekolah dan beranggapan bahasa Jawa sebagai pelajaran yang sulit. Pada kompetensi dasar membuat dan menyampaikan teks pidato masih mengalami kendala, karena masih kurangnya sarana dan prasarana untuk menunjang proses pembelajaran khususnya pada mata pelajaran bahasa Jawa. Salah satu upaya untuk meningkatkan kompetensi tersebut dengan menggunakan media pembelajaran video pepipak.

Tujuan dan fungsi pembuatan media video pepipak yaitu membuat siswa lebih tertarik dengan materi yang akan disampaikan, siswa lebih memahami tata cara untuk berpidato yang baik dan benar, dan untuk meningkatkan nilai siswa khususnya untuk materi pidato. Atmasandjaja (2007:12-21) menyatakan bahwa bekal yang dimiliki oleh orang yang akan melakukan pidato bahasa Jawa yaitu, (1) patrap atau sikap (2) busana lan ngadi sarira (3) Basal an sastra. Kuntari (2010:14-15) menyatakan bahwa lima hal yang harus diperhatikan ketika sesorah yaitu, wicara/basa, wirasa, wirama, wiraga, dan busana.

Pembelajaran pidato di sekolah biasanya disampaikan dengan buku panduan yang masih terpacu pada teori-teori sehingga siswa masih kesulitan. Hal ini menyebabkan siswa merasa bosan dengan pembelajaran yang masih konvensional sehingga dibutuhkan pembelajaran yang menyenangkan dan kreatif.

Guru dituntut untuk memiliki persiapan, baik metode ataupun media yang akan digunakan dalam proses pembelajaran sehingga dapat meningkatkan kelancaran dalam kegiatan dan hasil akhir dari proses pembelajaran. Media berfungsi sebagai alat bantu visual dalam kegiatan pembelajaran, yaitu berupa sarana yang dapat memberikan pengalaman visual kepada siswa antara lain untuk mendorong motivasi belajar, memperjelas dan mempermudah konsep yang kompleks dan abstrak menjadi lebih sederhana, konkrit, serta mudah dipahami. (Miarso dalam Musfiqon 2011:32).

Dalam proses belajar mengajar, fungsi media menurut Nana Sudjana (dalam Hamdan 2010) yaitu sebagai alat bantu untuk mewujudkan situasi belajar mengajar yang efektif, media pengajaran merupakan salah satu unsur yang harus dikembangkan guru, penggunaannya bersifat integral dengan tujuan dan isi pelajaran. penggunaan media dalam pengajaran bukan semata-mata sebagai alat hiburan yang digunakan hanya sekedar melengkapi proses belajar supaya lebih menarik perhatian siswa, penggunaan media dalam pengajaran lebih diutamakan untuk mempercepat proses belajar mengajar dan membantu siswa dalam menangkap pengertian yang diberikan guru.

Pembelajaran pidato dalam lingkungan sekolah sejatinya tidak susah dilakukan, caranya dengan memberikan media pembelajaran. Peran media sangat membantu dalam proses pembelajaran, siswa akan lebih mudah untuk belajar tanpa terpacu sama teori-teori saja, bukan 
Nur Izza Fadhliani, dkk/ Piwulang 8 (1) (2020)

hanya itu siswa akan lebih mudah untuk menerapkannya. Dengan penggunaan media pembelajaran berlangsung lebih efektif dan efisien, sehingga ada kemajuan dari hasil proses pembelajaran tersebut dan siswa bisa mendapatkan prestasi yang baik.

Penggunaan media video harus diperhatikan mengenai kualitas, validitas, kualitas media dengan dosen ahli materi dan dosen ahli media sehingga terlihat kualitas media yang sudah dikembangkan dan dijadikan pedoman oleh guru mata pelajaran bahasa Jawa serta siswa dalam pembelajaran.

Dari uraian di atas maka perlu adanya pengembangan media pembelajaran pidato untuk siswa kelas IX SMP/MTs ditegal. Media video dikemas dalam bentuk VCD (Video Compact Disk). Dalam media video para siswa dapat melihat objek secara langsung, sehingga memudahkan siswa untuk memahami pidato dan siswa dapat mengulang kembali materi di rumah dengan memutarnya.

\section{METODE PENELITIAN}

Penelitian pengembangan video pepipak merupakan penelitian yang menggunakan metode Research and Development menurut Sugiyono (2010:407). Sumber data penelitian ini meliputi siswa dan guru, sedangkan sumber data uji penilaian prototipe video pepipak yaitu guru dan uji ahli.

Teknik pengumpulan data menggunakan teknik observasi, wawancara, angket. Instrumen yang digunakan untuk mengumpulkan data mengenai media pidato berupa lembar observasi, pedoman wawancara dan kuesioner, angket kebutuhan siswa dan guru terhadap pembelajaran pidato berbahasa Jawa, angket validasi uji ahli dan guru. Analisis data penelitian menggunakan teknik analisis deskriptif kualitatif. Data-data yang ada dipaparkan kemudian disimpulkan.

\section{HASIL DAN PEMBAHASAN}

Media video pepipak dibuat berdasarkan hasil analisis kebutuhan guru dan siswa terhadap pembelajaran pidato berbahasa Jawa. Siswa membutuhkan media yang bahasanya mudah dipahami. Media video tersebut berisi tayangan video mengenai judul video, kompetensi dasar, indikator, contoh pidato yang diperagakan, dan yang terakhir gladhen atau latihan. Media dibuat untuk mempermudah siswa dalam memahami materi, mengaplikasikan dalam sebuah latihan, dan mempraktikan didepan kelas. Prototipe media video berdurasi 04 menit 18 detik, yang terdiri dari tiga sesi yaitu pembuka media, isi media dan penutup media.

Prototipe media video digambarkan dalam tabel storyboard dibawah ini.

\begin{tabular}{|l|l|l|l|}
\hline No & Slide & Isi & Audio \\
\hline 1. & Pembu & Berisikan & Backsound \\
& ka & judul media & istrumental \\
& Media & yang & Suara \\
& & penulisannya & pengucapan \\
& & dengan jenis \\
& font Time New \\
& & judul media \\
& & Roman, center \\
& text, font & \\
& & color putih, & \\
\hline
\end{tabular}


Nur Izza Fadhliani, dkk/ Piwulang 8 (1) (2020)

\begin{tabular}{|c|c|c|c|}
\hline & & $\begin{array}{l}\text { background } \\
\text { hitam, serta } \\
\text { diiringi } \\
\text { backsound } \\
\text { instrumental } \\
\text { rendah. }\end{array}$ & \\
\hline 2. & $\begin{array}{l}\text { Indikat } \\
\text { or }\end{array}$ & $\begin{array}{l}\text { Penulisan } \\
\text { point-point } \\
\text { indikator } \\
\text { yang harus } \\
\text { dicapai dalam } \\
\text { sebuah materi } \\
\text { penulisannya } \\
\text { dengan font } \\
\text { calibri, align } \\
\text { text, font } \\
\text { color putih, } \\
\text { background } \\
\text { hitam, serta } \\
\text { diiringi } \\
\text { backsound } \\
\text { instrumental } \\
\text { rendah. }\end{array}$ & $\begin{array}{l}\text { Backsound } \\
\text { instrumental }\end{array}$ \\
\hline 3. & $\begin{array}{l}\text { Isi } \\
\text { Media }\end{array}$ & $\begin{array}{l}\text { Contoh } \\
\text { pidato yang } \\
\text { diperagakan } \\
\text { oleh } \\
\text { seseorang, } \\
\text { contoh yang } \\
\text { disediakan } \\
\text { ada dua } \\
\text { contoh pidato } \\
\text { yaitu, satu } \\
\text { pidato hari } \\
\text { pendidikan }\end{array}$ & $\begin{array}{l}\text { Suara } \\
\text { mengenai } \\
\text { materi }\end{array}$ \\
\hline
\end{tabular}

\begin{tabular}{|l|l|l|l|}
\hline & & $\begin{array}{l}\text { nasional dan } \\
\text { yang kedua } \\
\text { pidato } \\
\text { kebersihan . }\end{array}$ & \\
\hline 4. & Penutu & $\begin{array}{l}\text { Tulisan } \\
\text { "matur } \\
\text { nuwun" } \\
\text { diiringi } \\
\text { dengan } \\
\text { iringan } \\
\text { instrumental } \\
\text { rendah }\end{array}$ & \\
\hline
\end{tabular}

Hasil validasi uji ahli digunakan untuk mengetahui kelayakan dan kualitas media yang dibuat. Berdasarkan penilaian dari uji ahli media mendapat presentase $78,82 \%$ yang termasuk kategori baik dengan beberapa bagian yang direvisi, dari pembuka media yang ditambah dengan identitas pembuat media, pemilihan font dan tambahan ucapan terima kasih dalam sesi penutup. Berdasarkan penilaian uji materi diperoleh $71.76 \%$ dengan kategori baik, dengan revisi bahasa yang digunakan dalam contoh teks pidato, bahasa yang digunakan pada media video menggunakan bahasa ngoko (dialek ragam tegal) yang dipahami oleh siswa, sesuai dengan angket kebutuhan yang telah diisi.

\section{SIMPULAN}

Berdasarkan analisis kebutuhan pembelajaran pidato berbahasa Jawa yang diisi oleh siswa dan guru, siswa dan guru membutuhkan media pembelajaran pidato berbahasa Jawa dengan konsep video pidato. Konsep video pidato 
Nur Izza Fadhliani, dkk/ Piwulang 8 (1) (2020)

menggunakan bahasa yang mudah dipahami oleh siswa yaitu bahasa ngoko (ragam ngapak tegal), dengan tambahan istrument musik, rekaman audio. Jenis pidato yang digunakan yaitu sambutan, membutuhkan dua contoh pidato.

Prototipe video pidato berdasarkan hasil analisis kebutuhan pembelajaran pidato berbahasa Jawa untuk siswa dan guru mencakup beberapa hal yaitu: sampul kotak pembungkus VCD, label VCD, isi VCD. Dalam isi VCD pidato berdurasi 04 menit 18 detik yang terdiri dari tigs sesi, yaitu: pembukaan media, isi media, dan penutup media. Tahap awal yaitu pembuatan naskah, berdasarkan naskah tersebut diperoleh bahan-bahan seperti: video pidato, instrument musik, audio, setelah bahan terkumpul proses akhir yaitu editing video atau proses produksi.

Hasil uji ahli menunjukkan protitipe media video pidato diperoleh dari hasil uji ahli media dan uji ahli materi masing-masing memperoleh presentase $78.82 \%$ dan $71.76 \%$ yang masuk kategori baik dengan beberapa revisi penambahan pada pembukaan media, bahasa yang digunakan pada teks pidato dirubah sesuai dengan angket kebutuhan siswa terhadap pembelajaran pidato berbahasa Jawa, penambahan di penutup media yaitu ucapan terima kasih.

\section{DAFTAR PUSTAKA}

Hamdani. 2011. Strategi Belajar Mengajar. Bandung: CV Pustaka Setia.
Kosasih, E. 2008. Terampil Berbicara di depan Umum. Jakarta: Penerbit Nobel Edumedia.

Kuntari, Umi. 2010. Tuntunan Lengkap Pranatacara Sing Kepenak, Luwes, Tur Nyenengake. Yogyakarta: Pinus Book Publisher.

Musfiqon. 2012. Pengembangan Media dan Sumber Pembelajaran. Jakarta: Prestasi Pustaka Publisher.

Sugiyono. 2013. Metode Penenlitian Pendidikan (Pendekatan kuantitatif, kualitatif, dan R\&D). Bandung: ALFABETA.

Yuniawan, Tommi. 2012. Terampil Retorika Berbicara. Semarang: Unnes Press. 